\title{
Exploring the Interpurchase Time of Two Interdependence Brands with Bivariate Stochastic Model
}

\author{
H. H. Huang \\ Department of Business Administration \\ Aletheia University \\ Taiwan
}

\begin{abstract}
In the competitive E-commerce marketing, a customer may purchase two or more different brands in one product categories. These brands become the competitive brands to win the customer's share of the wallet. Thus it is an important issue to explore the interpurchase time of two interdependence and competitive brand. This paper proposes a bivariate model with stochastic approach to predict customer purchase behavior. These results can provide the application of E-commerce system.
\end{abstract}

Keywords-data mining; interpurchase time; bivariate model; customer purchase behaviour

\section{INTRODUCTION}

In the e-commerce marketing, customers will purchase not only one brand in a period of time but will be variety seeking or make purchase between two or more brands [1]. Because the various brand choice and convinces marketing place, customer are easy to switch between two or more brands. Thus, the interpurchase time between two brands is not dependent. There is some case effect in different ordinary of brand purchasing. The time interval of first purchasing may influence the next purchase. Therefore, the purchase behavior between these two brands of this customer may have some correlated. In this research, we propose a model to discuss the interdependence in purchase timing between the two brands with a bivariate stochastic approach.

\section{LITERATURE REVIEW}

Chintagunta and Haldar[2]investigate purchase timing behavior in two related product categories. They find that the impact of price reductions in one category on the purchase probabilities in both categories and the bivariate hazard functions to be nonmonotonic in nature. [3] proposes an interpurchase time model for associated products to describe how likely a product will be bought after its associated product is bought. In the research of Chintagunta and Haldar [2], they base on the model of Farlie-Gumbel-Morgenstern family of bivariate distributions [4] to combine two independent univariate distributions into a correlated bivariate distribution. Huang [5] also uses this model to explore the relations between purchase monetary and interpurchase time of customer behavior and find it is useful to forecast bivariate variables. Thus this study adopt the model of Farlie-Gumbel-Morgenstern with transforming metric to develop our interpurchase time of two Interdependence Brand model.
III. THE MODEL

We assume that a customer purchase two brands, A and B in one categories and the interpurchase time of each brand can be demonstrated as following.

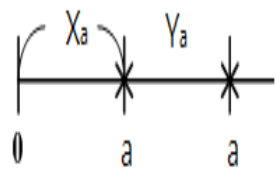

FIGURE I. THE CUSTOMER WHO ONLY PURCHASE BRAND A

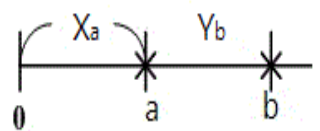

FIGURE II. THE CUSTOMER WHO ONLY PURCHASE BRAND B

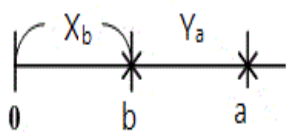

FIGURE III. THE CUSTOMER WHO FIRST PURCHASE BRAND A THEN BRAND B

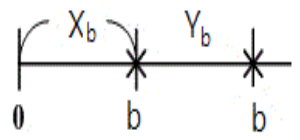

FIGURE IV. THE CUSTOMER WHO FIRST PURCHASE BRAND B THEN BRAND A

$\mathrm{X}$ is the interpurcase time of first purchasing, $\mathrm{Y}$ is second time-interval of interpurchase. We consider $\mathrm{X}, \mathrm{Y}$ are two related random variables. In Figure 1 and Figure 4, the customer only purchases one brand at both first and later times and its interpurchase times are respectively $\mathrm{X}_{\mathrm{a}}, \mathrm{Y}_{\mathrm{a}}$ (when purchase brand a) or $\mathrm{X}_{\mathrm{b}}, \mathrm{Y}_{\mathrm{b}}$ (when purchase brand $\mathrm{b}$ ). In Figure 2 and 3 , the customer purchase two different brands at first and later times. According the ordinary of brand purchasing time, its interpurchase times are respectively $\mathrm{X}_{\mathrm{a}}, \mathrm{Y}_{\mathrm{b}}$ or $\mathrm{X}_{\mathrm{b}}, \mathrm{Y}_{\mathrm{a}}$. 
According Farlie-Gumbel-Morgenstern family of bivariate distributions[4],

$$
\begin{aligned}
& F_{a, b}(x, y ; \alpha)=F_{a}(x) F_{b}(y)\left\{1+\alpha\left[1-F_{a}(x)\right]\left[1-F_{b}(y)\right]\right\} \\
& f_{a, b}(x, y ; \alpha)=f_{a}(x) f_{b}(y)\left\{1+\alpha\left[1-2 F_{a}(x)\right]\left[1-2 F_{b}(y)\right]\right\} .
\end{aligned}
$$

This equation is demonstrated the customer who purchase brand $\mathrm{A}$ with its interpurcahse time $\mathrm{x}$ and purchase brand $\mathrm{B}$ with its interpurcahse time $y$. Then, the customer purchase brand $\mathrm{A}$ with its interpurcahse time $\mathrm{x}$ and brand $\mathrm{A}$ again with its interpurcahse time y will be defined (3). Equation (4) is described the customer who purchase brand $\mathrm{B}$ with interpurchase time $\mathrm{x}$ and also purchase brand $\mathrm{B}$ again in $\mathrm{y}$ interpurchase time.

$$
\begin{aligned}
& f_{a, a}(x, y ; \alpha)=f_{a}(x) f_{a}(y)\left\{1+\alpha\left[1-2 F_{a}(x)\right]\left[1-2 F_{a}(y)\right]\right\} \\
& f_{b, b}(x, y ; \alpha)=f_{b}(x) f_{b}(y)\left\{1+\alpha\left[1-2 F_{b}(x)\right]\left[1-2 F_{b}(y)\right]\right\}
\end{aligned}
$$

We assume that the probability of purchase behavior is demonstrated in table 1 with four scenarios:

TABLE I. THE PROBABILITY OF PURCHASE BEHAVIOUR

\begin{tabular}{|l|l|l|}
\hline & $\begin{array}{l}\text { Purchase brand } \boldsymbol{a} \text { at } \\
\text { first time }\end{array}$ & $\begin{array}{l}\text { Purchase brand } \boldsymbol{b} \\
\text { at first time }\end{array}$ \\
\hline $\begin{array}{l}\text { Purchase } \\
\text { brand } \boldsymbol{a} \\
\text { later time }\end{array}$ at & $\begin{array}{l}\text { Purchase brand } a \text { at } \\
\text { two times } p_{11}\end{array}$ & $\begin{array}{l}\text { Purchase brand } b \text { at } \\
\text { first time, Purchase } \\
\text { brand } a \text { at later } \\
\text { time }\end{array}$ \\
\hline $\begin{array}{l}\text { Purchase } \\
\text { brand } \boldsymbol{b} \\
\text { later time }\end{array}$ & $\begin{array}{l}\text { Purchase brand } a \text { at } \\
\text { first time, Purchase } \\
\text { brand } b \text { at later time } \\
p_{21}\end{array}$ & $\begin{array}{l}\text { Purchase brand } b \text { at } \\
\text { two times }\end{array}$ \\
\hline
\end{tabular}

The probability of these four situations are the metric as following,

$$
p=\left[\begin{array}{ll}
P_{11} & 1-P_{11} \\
P_{21} & 1-P_{21}
\end{array}\right]
$$

Then we can calculate the cumulative density function of $y_{a}$

$$
\begin{aligned}
& p\left(Y_{a}<y_{a}\right) \\
& =\left[\int_{0}^{\infty} p\left(Y_{a}<y_{a} \mid X_{a}=x_{a}\right) \cdot f_{a}\left(x_{a}\right) d x_{a}\right] \cdot P_{11} \\
& +\left[\int_{0}^{\infty} p\left(Y_{a}<y_{a} \mid X_{b}=x_{b}\right) \cdot f_{b}\left(x_{b}\right) d x_{b}\right] \cdot P_{21} \\
& \left.\left.=f_{a}\left(y_{a}\right)\right]_{0}^{\infty} p_{11}+f_{a}\left(y_{a}\right)\right]_{0}^{\infty} p_{21} \\
& =F_{a}\left(y_{a}\right) p_{11}+F_{a}\left(y_{a}\right) p_{21}
\end{aligned}
$$

\section{THE EMPIRICAL ILLUSTRATION OF THE MODEL}

We take our sample from the customer database of two commercial credit-card banks, bank A and bank B in Taiwan. For both banks, our data draws on the duration of a certain customer from the first transaction with this credit card until the cancellation of this card. Both customers' consumption periods are from January 2, 2006 to December 31, 2008. There are 3335 customers and 27592 transactions. Then we complete the calculations of the transform between brand A and brand B and no transforming as table 2 .

TABLE II. The Cumulative Numbers of Transforming PuRchase BEHAVIOUR

\begin{tabular}{|l|l|l|}
\hline & $\begin{array}{l}\text { Purchase brand } \\
\boldsymbol{a} \text { at first time }\end{array}$ & $\begin{array}{l}\text { Purchase brand } \boldsymbol{b} \text { at } \\
\text { first time }\end{array}$ \\
\hline $\begin{array}{l}\text { Purchase } \\
\text { brand } \boldsymbol{a} \text { at time } \\
\text { later time }\end{array}$ & 5925 & 2033 \\
\hline $\begin{array}{l}\text { Purchase } \\
\text { brand b at } \\
\text { later time }\end{array}$ & 4833 & 1005 \\
\hline
\end{tabular}

We use the propotions of each state in the total numbers of time interval to caculate the Markov chain propability as (7). We consider the interpurchase time follows exponental distribution with parameters $\lambda_{\mathrm{a}}, \lambda_{\mathrm{b}}, \theta_{\mathrm{a}}, \theta_{\mathrm{b}}$. Finally, the $F\left(y_{a}\right)$ (see equation (6)) can also be obtained.

$$
p=\left[\begin{array}{ll}
P_{a a} & P_{b a} \\
P_{a b} & P_{b b}
\end{array}\right]=\left[\begin{array}{ll}
0.429 & 0.147 \\
0.350 & 0.073
\end{array}\right]
$$

\section{THE CONCLUSION}

This paper proposes a stochastic model to portray the interpurchase time between two competitive but relative brands This model can be used to predict customer purchase behavior and this information can provide the retails for manufacturing forecasting.

\section{REFERENCES}

[1] Jacoby, J.\& Kyner, D. B., Brand loyalty vs. repeat purchasing behavior, Journal of Marketing Research, 10(1), pp. 1-9, 1973.

[2] Chintagunta, P. K. \& Haldar, S., Investigating purchase timing behavior in two related product categories, Journal of Marketing Research, 35(1), pp. 43-53, 1998 .

[3] Cheng, C. I., Associated map and inter-purchase time model for multiple-category products, Journal of International Business Studies, $8(2), 2014$.

[4] Johnson, N. L. \& Kotz, S., On some generalized Farlie-GumbelMorgenster distributions, Communications in Statistics, 4 (5), pp.415-27, 1975.

[5] Huang, H. H., Data mining application of marketing: a bivariate model of customer purchase monetary and interpurchase time, Information and Knowledge Management, 45, pp.154-157, 2012.

where

$P_{21}+P_{21}=1$ 